\title{
Factors Influencing Professional Judgment of Auditors in Malaysia
}

\author{
Hazianti Abdul Halim ${ }^{1}$, Hartini Jaafar ${ }^{1}$, Sharul Effendy Janudin ${ }^{1}$ \\ ${ }^{1}$ Senior Lecturer, Department of Accounting and Finance, Faculty of Management and Economics, Universiti \\ Pendidikan Sultan Idris, Perak, Malaysia \\ Correspondence: Hazianti Abdul Halim, Department of Accounting and Finance, Faculty of Management and \\ Economics, Universiti Pendidikan Sultan Idris, Perak, Malaysia. \\ Received: September 19, 2018 \\ Accepted: October 10, $2018 \quad$ Online Published: October 16, 2018 \\ doi:10.5539/ibr.v11n11p119 \\ URL: https://doi.org/10.5539/ibr.v11n11p119
}

\begin{abstract}
The purpose of this study was to examine the factors influencing professional judgment of Malaysian auditors. A questionnaire was used to measure the level of professional judgment and factors influencing the judgment such as gender, knowledge, position level, experience and also firm size. The multiple regression results showed that the position level and experience to be statistically significant in determining the level of professional judgment of auditors. Gender, knowledge and firm size have no significant relationship with professional judgment. As for gender, past research has shown mixed results and this study proves that there is no gender differences among Malaysian auditors in terms of their professional judgment. Even though past research has shown that knowledge has a positive relationship with professional judgment, this study finds no significant relationship between the two variables. With regard to firm size, this study finds similar results of prior study that there is no significant relationship between firm size and judgment. In terms of the practical implications, this study provides insights into significant factors that influence professional judgment of Malaysian auditors. Besides, the management of audit firms can place emphasis on establishing training to their employees especially for the junior staff. Exposing junior auditors at the early stage might improve their professional judgment when facing with complexities of assignments.
\end{abstract}

Keywords: auditors, Malaysia, professional judgment

\section{Introduction}

Professional judgment among accounting professionals has always been a subject to scrutiny both in practice and also literature. In auditing, professional judgement is about practising related knowledge and experience in auditing based on the accounting and auditing standards and professional code of ethics to make a sound decision-making. In addition, the accounting and auditing discipline has increasingly recognised professional judgment as one of the highly important attributes in the profession. Besides financial reporting, which are influenced by factors such as accounting standards, economic factors and professional ethics and responsibilities, auditing also involved a critical professional judgement. The public can rely on an auditor's representations when confidence exists that the auditor has acted as an impartial judge, basing conclusions on objective evidence (Mansouri, Pirayesh, \& Salehi, 2009).

The International Auditing and Assurance Standards Board (IAASB) issues international standards for auditing and other assurance and related services and these standards are now used by more 100 countries in the world. In addition to this, there is also the International Ethics Standards Board for Accountants (By-Laws on Code of Ethics) that issues ethical standards and guidance for use by professional accountants. In Malaysia, the Malaysian Institute of Accountants (MIA) has adopted this standard and renamed the code as MIA By-Laws (Eilisfsen et. al, 2014) and this code provides guidelines for professional accountants with regard to fundamental ethical principles.

Because financial statement audits play an important role in economy, the public put absolute trust in accounting and auditing professionals as these profession exemplified high moral values and integrity (Haron, Ismail, Ibrahim, \& Na, 2014). Auditors should maintain a high standard of professional conduct and exercise professional judgment in their work, failure of which, may result in civil damages or even criminal penalties. In addition, professionalism means using technical and communication skills and values. Unbiased professional judgement by auditors is an important assumption of professional standards. However, the complexities of 
today's accounting and auditing process become one of the serious challenges to auditors (Heyrani, Banimahd, \& Roudposhti, 2016).

Prior research has documented that there are various factors that could influence how auditors exercise their professional judgement. For example, personal characteristics such as gender influences how auditors behave. For example, with regard to higher ethical values female are less likely to engage in unethical behaviour as compared to male (Haron et al., 2014). In addition to gender, cultural factors such as different races also influence the behaviour of auditors (Patel, Harrison, \& McKinnon, 2002). Besides personal characteristics, factors such as audit work environment, auditor's independence, audit evidences and the process of decision making do influence professional judgment of auditors. Therefore, it is argued in this study that there are different factors that could influence how auditors in Malaysia exercise their professional judgment, particularly in addressing the new auditor's report with the new key audit matters. Therefore, the objectives of this study are (i) to examine the level of professional judgment of auditor and (ii) to identify the factors influencing professional judgment of auditors in Malaysia, namely gender, culture, firm size, position level and experience. In order to achieve these objectives, six research questions are formulated which are:

1) What is the level of professional judgment of Malaysian auditors?

2) Does gender influence professional judgment of Malaysian auditors?

3) Does knowledge influence professional judgement of Malaysian auditors?

4) Does position level influence professional judgement of Malaysian auditors?

5) Does experience influence professional judgement of Malaysian auditors?

6) Does firm size influence professional judgement of Malaysian auditors?

This study makes important theoretical contributions. This is because it extends the literature of factors influencing professional judgement of auditors by providing information on experience and also position level of auditors particularly among Malaysian auditors. From a practical perspective, this research is expected to benefit the professional accountants and also auditors as best practices mechanisms can work toward effective professional judgement. This research benefits the regulatory bodies such as MASB and MIA in order to help them strengthening the profession.

\subsection{Literature Review}

With regard to professional judgment of auditors, a stream of research has been conducted to determine the level of professional judgment and its various contributing factors. These studies have examined factors such as personal characteristics and experience of auditors, firm size, and also position level regarding what and how these factors influenced auditors' professional judgement. However, prior studies provide inconsistent results regarding the factors related to professional judgment. Therefore, further investigations are necessary so that issues that hinder the consistencies of results can be addressed and more conclusive evidence can be drawn.

In essence, the principles-based approach requires accountants to make professional judgments on the substance rather than their legal form (Agoglia, Doupnik, \& Tsakumis, 2011; Psaros \& Trotman, 2004). Bennett, Bradbury, \& Prangnell (2006) argued that a relatively more principles-based standards regime requires professional judgment at both the transaction level (substance over form) and at the financial statement level ('true and fair view' override). This is because the IFRS require exercise of more professional judgement. Judgement has always been a critical issue of both the preparation and of audits of financial statements. In this regard, concerns about the subjectivity and possible variability of accountants' judgements cast some doubt on the operational effectiveness of the conceptual approach. Some has also argued that to some extent principles-based approach leads to biased financial reporting (Bennett et al., 2006). This is due to the fact that the IFRS allow preparers to apply judgement in selecting reporting methods, estimates and disclosures that match firms' underlying economics. The use of judgement, however, also presents the opportunity for management to select methods and estimates to achieve desired earnings figure (Smieliauskas, 2012).

\subsection{Factors Influencing Professional Judgement}

Prior research documented that there are various factors that can be associated with good professional judgement. According to Emby \& Gibbins (1987) expectation, outcome, and justification perspectives on judgment quality are among factors that influence the accountants' judgement. From the perspective of public accountants, they see these factors as important in defining good judgment with variations related to position (level of responsibility). This study is supported by Ponemon (1990) who documented that there is an association between the way in which auditors resolve dilemma and their position level. Although the primary focus of good auditor 
judgments and audit quality is at the early stage, the current regulatory environment and the structure of audit firms are of increased importance in influencing those judgments. These factors also influence the independence and professional scepticism of auditors and how audit evidence combines with auditor knowledge, traits, and incentives to produce judgments that reflect professional scepticism (Wedemeyer, 2010).

\subsubsection{Gender}

Auditor judgment is observed as one of the most important elements of a financial statement audit and defined as "any decision or evaluation made by an auditor, which influences or governs the process and outcome of an audit of financial statements" (Wedemeyer, 2010). Auditors use their judgments when they make major decisions such as: "(1) the assessment of the risks of material misstatements of financial statements, including the potential effects of fraud, bias and business risk; (2) the identification, performance and assessment of audit procedures to address those risks; (3) the evaluation of audit evidence to determine the quality and meaning of that evidence and to assess the need for additional evidence based on the process; and (4) the formation of an opinion on the financial statements and the decision whether or not to express that opinion" (Wedemeyer, 2010).

Gender has typically been treated as a personal characteristic or an indicator which is supposed affect both affective and continuous commitment. In other words, the influence of some organisational practices may be different for men and women (Haron et al., 2014). For example Fumagalli et al. (2010) find that moral judgment does differ between gender. In addition to that, Shawver and Clements (2015) indicate that female accountants were more sensitive to business situations involving earnings management and viewed earnings management actions as less ethical than male accountants. In a study involving 166 participants from business classes, Barnett, Brown, and Bass (1994) examined the ethical judgments of the students regarding 24 business-related scenarios. These scenarios included, amongst others, "a worker passing blame for errors to an innocent co-worker, a worker claiming credit for someone else's work, an employee following management directives and not informing an auto manufacturer about a faulty component part, a manager authorizing a subordinate to violate company rules, a management decision that violates the privacy of subjects during a marketing research study" (Barnett, Brown \& Bass, 1994, p.335). The results of their study showed significant differences in the ethical judgments of participants based on gender in 22 of the 24 cases, with male students judging all the actions described in the scenarios to be less unethical than the female students. These gender differences, as Barnett, Brown, and Bass (1994) further explained, indicated that males' moral development might be slower than that of females, or that males' approach towards moral dilemmas might be more pragmatic.

Previous behavioural accounting research focusing on gender differences in auditors' judgments has produced mixed results. While some researchers have seen no differences in judgments between male and female auditors (Haron et al., 2014; Jamilah, Fanani, \& Chandr, 2007; Ponemon, 1990; Setiawan, 2018) others have found empirical evidence of significant gender differences in decision-making processes (Chung \& Monroe, 2001, Pajouh \& Martin, 2018). A study on auditors by Chung \& Monroe (2001) find that gender plays an important role with regard to audit judgment. It was argued that female auditors were more accurate as compared to their male counterparts. It can be argued that this lack of gender differences may be caused by work-related socialisation, occupational roles, similar training, the structure of the business world, and professional standards.

\subsubsection{Knowledge}

A considerable amount of research associated with auditor judgment has produced several concerns about how knowledge might affect the approach to audit judgment and to help auditors in better decision making (Mala \& Chand, 2015). Auditors acquire knowledge through education, training, and experience (Bhattacharjee \& Moreno, 2002). In this regard, a considerable amount of research have been carried out to determine how audit tasks are carried out and what kind of education and training would assist individuals, which include how knowledge might affect the approach to judgment and help in better decision making (Mala \& Chand, 2014).

\subsubsection{Position Level}

Studies on ethical behaviour found that individuals of higher rank have a stronger sense of obligation to their profession than those in a lower rank. This means the attention to ethical principles increases as the level of responsibilities increases. In earlier study, Ponemon (1990) investigate possible relationship between moral reasoning and position and found that auditors' position level in the firm influence ethical reasoning and judgment. This is because, according to the study, higher position means auditors pays more attention to external forces such as firm's profit. Moreover, auditors who hold a higher position such managers and partners display greater management skills than auditors of lower position. However, (Haron et al., 2014) find no significant relationship between position level and ethical judgment. 


\subsubsection{Experience}

Besides knowledge and position level, experience has also been identified as possible factors that may influence an auditor's performance. Bonner (1994) note that although experienced auditors have a stronger performance than auditors with less experience and knowledge, they provide a better explanation for the difference in their performance. In addition, Libby \& Frederick (1990) find that experienced auditors have a more complete understanding of the errors in the financial statement and are able to explain them. They conclude that experienced auditors can reach a proper conclusion more quickly than their less experienced colleagues.

In another study, Bhattacharjee \& Moreno (2002) find that more experienced auditors are able to ignore irrelevant information while making judgment while less experienced auditors are not. Less experienced auditors incorporated irrelevant negative information into their judgment, resulting in higher risk assessment ratings. Quite recently, Farma, Karamoy, \& Datu (2016) ; Limen, Karamoy, \& Gamaliel (2017) and Ríos-figueroa \& Este (2013) examine whether experience could affect the professional judgment of auditors during the planning phase of an audit. However, they discover that experience does not significantly affect professional judgment. In other words, auditors with less experience does not seem to have a significant difference on professional judgment.

\subsubsection{Firm size}

Some studies argue that how auditors behave including their independence is influenced by the size of audit firms (Abu Bakar \& Ahmad, 2009). These studies observed that as the number of dilemmas faced by small firms' personnel increases, the level of moral reasoning increases (Clarke et al 1996). Generally, small audit firm do not have formal in-house training on which to rely. However, Sweeney (1995) find that firm size is not related to moral practice and judgment. Likewise, Haron et al. (2014) find no significant relationship between firm size and ethical judgment.

\subsection{Hypotheses Development}

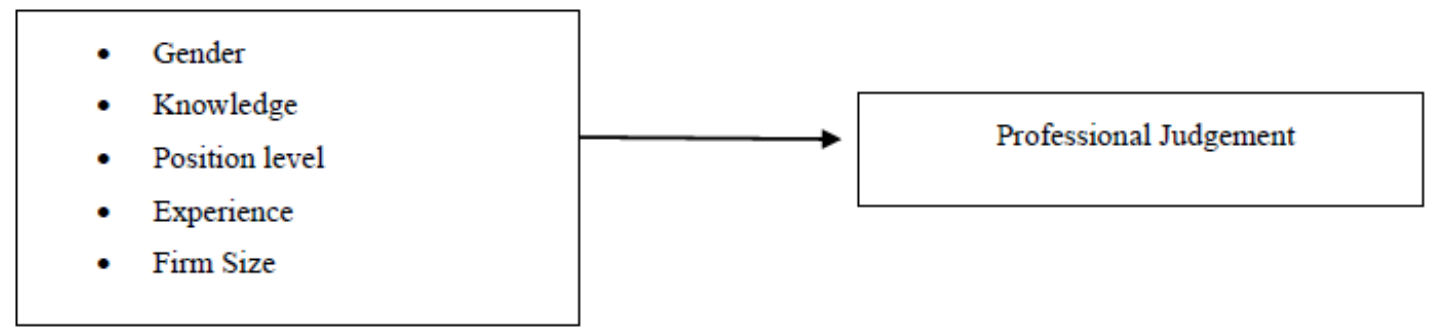

Figure 1. Theoretical Framework

Figure 1 shows the theoretical framework for this study. Based on the theoretical framework of the current study, five general hypotheses are developed.

\subsubsection{Professional Judgment and Gender}

Findings related to the influence of gender on professional judgment are mixed. Some studies have suggested that with regard to professional judgment, women are more prominent, whereas others have reported that gender and professional judgement are not correlated. Based on the discussion presented in the previous section, findings regarding gender and professional judgment are mixed and, therefore, this hypothesis is proposed:

\section{H1: Gender influence the level of professional judgment of Malaysian auditors.}

\subsubsection{Professional Judgment and Knowledge}

A considerable amount of research have been carried out to determine how audit tasks are carried out and the types of education and training would assist individuals, or how knowledge might affect the approach to judgment and help in better decision making (Mala \& Chand, 2014). Therefore, the next hypothesis is proposed:

\section{H2: Knowledge and the level of professional judgment of Malaysian auditors are positively related.}

\subsubsection{Professional Judgment and Position Level}

As previously discussed, many studies on ethical behaviour found that individuals with higher position have a stronger sense of commitment or obligation to their profession than those in a lower position. Therefore, the following hypothesis is proposed:

\section{H3: Position level and the level of professional judgment of Malaysian auditors are positively related.}




\subsubsection{Professional Judgment and Experience}

In this study, we consider whether the number of years of experience of auditors influence their level of professional judgment. This is because some studies conclude that experienced auditors perform better than their less experienced colleagues. Therefore, the following hypothesis is proposed:

H4: Experience and the level of professional judgment of Malaysian auditors are positively related.

\subsubsection{Professional Judgment and Firm Size}

As previously discussed, some studies argue that behaviour of auditors is influenced by the size of audit firms. They highlighted that as the number of dilemmas faced by small firms' personnel increases, the level of moral reasoning increases. Therefore, the following hypothesis is proposed:

H5: Firm size and the level of professional judgment of Malaysian auditors are positively related.

\section{Method}

Data were collected using survey questionnaire administered to the following groups: senior auditors, junior auditors and audit managers of audit firms in the Klang Valley area. The questionnaires were distributed during May to July 2018. A total of 55 usable responses were received. The questionnaires consist of three sections. Section A requires demographic information such as gender, age, religion, years of experience, professional qualification, position level and also company category. Section B measures knowledge and Section C measures professional judgment. Four statements measure knowledge and eight statement measures professional judgment. These sections require respondents to choose the appropriate response from the 5-point Likert scale from one (strongly disagree) to five (strongly agree). The responses derived from the questionnaires are coded, entered and analysed by using the SPSS statistical package. The questionnaire was pilot tested by administering the questionnaire to final year accounting students in one of public universities in Malaysia. Their feedback was recorded and several additional changes were made. A reliability test was carried out to ensure the internal consistency of the instrument. All items possessed Cronbach's Alpha's value of more than $80 \%$ and this indicates that the internal consistency of the instrument is good and therefore, acceptable. 


\section{Results}

\subsection{Profile of Respondents}

Table 1. Profile of Respondents

\begin{tabular}{|c|c|c|c|}
\hline Demographic Variables & Category & Frequency $(\mathrm{n}=53)$ & Percentage (\%) \\
\hline \multirow{2}{*}{ Gender } & Male & 17 & 32.1 \\
\hline & Female & 36 & 67.9 \\
\hline \multirow[t]{3}{*}{ Race } & Malay & 40 & 75.5 \\
\hline & Chinese & 9 & 17 \\
\hline & Indian & 4 & 7.5 \\
\hline \multirow[t]{4}{*}{ Religion } & Islam & 40 & 75.5 \\
\hline & Buddhism & 5 & 9.4 \\
\hline & Hinduism & 4 & 7.5 \\
\hline & Christianity & 4 & 7.5 \\
\hline \multirow[t]{5}{*}{ Age } & Below 26 & 35 & 66 \\
\hline & $26-31$ & 10 & 18.9 \\
\hline & $31-35$ & 2 & 3.8 \\
\hline & $36-40$ & 4 & 7.5 \\
\hline & Above 40 & 2 & 3.8 \\
\hline \multirow[t]{3}{*}{ Highest Level of Education } & Degree & 40 & 75.5 \\
\hline & Masters & 2 & 3.8 \\
\hline & Professional Qualification & 11 & 20.8 \\
\hline \multirow[t]{3}{*}{ Professional Qualification } & None & 28 & 52.8 \\
\hline & Less Than 2 & 16 & 30.2 \\
\hline & More Than 2 & 9 & 17 \\
\hline \multirow[t]{5}{*}{ Years Being Members of MIA } & Non Member & 41 & 77.4 \\
\hline & Less Than 4 & 5 & 9.4 \\
\hline & $4-6$ & 2 & 3.8 \\
\hline & $7-9$ & 2 & 3.8 \\
\hline & More Than 9 & 3 & 5.7 \\
\hline \multirow[t]{3}{*}{ Position Level } & Junior & 35 & 66 \\
\hline & Senior & 12 & 22.6 \\
\hline & Manager & 6 & 11.3 \\
\hline \multirow[t]{5}{*}{ Income } & RM 3,000 and below & 36 & 67.9 \\
\hline & RM 3,001 - RM 4,000 & 6 & 11.3 \\
\hline & RM 4,001 - RM 5,000 & 4 & 7.5 \\
\hline & RM 5,001 - RM 6,000 & 1 & 1.9 \\
\hline & RM 6,001 and above & 6 & 11.3 \\
\hline \multirow[t]{5}{*}{ Years working in Present Company } & Less than 2 & 42 & 79.2 \\
\hline & $2-3$ & 2 & 3.8 \\
\hline & $4-6$ & 7 & 13.2 \\
\hline & $7-9$ & 1 & 1.9 \\
\hline & More than 9 & 1 & 1.9 \\
\hline \multirow[t]{4}{*}{ Years Being an Auditors } & Less than 4 & 41 & 77.4 \\
\hline & $4-6$ & 7 & 13.2 \\
\hline & $7-6$ & 3 & 5.7 \\
\hline & More than 9 & 2 & 3.8 \\
\hline \multirow[t]{2}{*}{ Company Category } & Big Four & 13 & 24.5 \\
\hline & Non - Big four & 40 & 75.5 \\
\hline
\end{tabular}

Table 1 shows that $33 \%$ of the respondents are male and $67 \%$ female. Based on the table, almost $80 \%$ of the respondents are Muslim. The respondents are mostly below 26 years old and possessed a degree. Around $20 \%$ of the respondents possessed professional qualifications. In addition to that, $66 \%$ of the respondents hold junior position and 34\% hold senior and managerial position. This explains the number of years of experience because $77 \%$ of the respondents have less than four years as auditor. Finally, 25\% of the respondents are from Big Four firms and the remaining are from Non-Big-Four firms.

\subsection{Mean Value of Professional Judgment}

Section $\mathrm{C}$ has eight statements that measure the level of professional judgement of the respondents. Respondents were asked to rate their responses through a 5-point Likert scale of one (strongly disagree) to five (strongly agree).

\subsection{Hypotheses Testing}

Multiple Regression Analysis

The basic model is:

PROFJUDG $=\beta 0+\beta 1$ GENDER $+\beta 2$ KNOWLEDGE $+\beta 3$ POSITION LEVEL $+\beta 4$ EXPERIENCE $+\beta 5$ 


\section{FIRM SIZE $+€$}

All assumption of the model, including the normality of the error term, homoscedasticity, autocorrelation, linearity of the relationship and independent of the independent variables were fulfilled.

Table 2. Multiple Regression Results

\begin{tabular}{llllll}
\hline Model & \multicolumn{2}{l}{ Unstandardized coefficients } & $\begin{array}{l}\text { Standardized } \\
\text { coefficients }\end{array}$ & \\
\hline & B & Std error & $\mathrm{B}$ & $\mathrm{t}$ & Sig. \\
(Constant) & 0.160 & 0.151 & & 1.061 & 0.294 \\
Gender & 0.003 & 0.044 & 0.002 & 0.074 & 0.942 \\
Position level & 0.187 & 0.077 & 0.137 & 2.427 & $0.019^{*}$ \\
Knowledge & 0.020 & 0.049 & 0.016 & 0.405 & 0.688 \\
Experience & 0.870 & 0.043 & 0.879 & 20.211 & $0.000^{*}$ \\
Firm size & 0.006 & 0.053 & 0.003 & 0.122 & 0.903 \\
\hline Adjusted R ${ }^{2}:$ & & & & 0.476 & \\
Standard error: & & & & 0.14757 & \\
\hline
\end{tabular}

Dependent Variable: Professional Judgment

*Significant at $5 \%$ confidence level $(\mathrm{p}<0.05)$

The regression results indicate that $47 \%$ of the variation in professional judgment level is explained by independent variables. Results show that position level and experience are significant at 5\% significance level. Both variables show a positive relationship with professional judgement. The other variables are not significant in relation to professional judgment.

\section{Discussion}

Overall, this study developed five (5) hypotheses. $\mathrm{HI}$ related to the influence of gender on the level of professional judgment of Malaysian auditors. The expectation was that gender would, to some extent influence the level of professional judgment of auditors. However, the results show no significant influence of gender with regards to professional judgment; hence, does not provide support to $H 1$. The results of this study support findings by Haron et al (2014), Jamilah et al (2007) and Ponemon (1990) that in terms of judgment, there is no differences between male and female auditors. This lack of gender differences may be caused by work-related socialization, similar training and also the professional standards that may eliminate differences between male and female auditors.

$H 2$ expected a positive association between professional judgment and knowledge. However, the results showed no association between the variables. Hence, $H 2$ is not supported. It can be argued here that even though auditors acquire knowledge through education and training (Bhattacharjee \& Moreno, 2002), knowledge is not significant in explaining the variation in professional judgment. $H 3$ predicted a positive relationship between professional judgment and position level. Position level was found to be statistically significant and therefore, provide support for $H 3$. However, an earlier study conducted in Malaysia found no significant relationship between position level and judgment (Haron et al, 2014). It was argued in the study that more stringent rules and regulations will change the judgment of auditors. The higher the auditors perceived the ethical climate of the organisation, the more ethical they will be and not because of their position level. In contrast, our findings is similar to Ponemon (1990) and Praditaningrum (2012) who found that position level is positively associated with the level of judgment of auditors.

H4 posited a positive relationship between experience and professional judgment. The results revealed a significant positive relationship between experience and professional judgment of Malaysian auditors and hence, provide support for $H 4$. This results are similar to prior studies which found that experience have positive and significant impacts on audit judgment (Bhattacharjee \& Moreno, 2002; Griffith et al, 2017; Mala \& Chand, 2014 and Safi'i \& Jayanto, 2015). Therefore, it can be concluded that more experienced Malaysian auditors provide higher level of professional judgment as compared to their counterparts. The final hypothesis, H5 expected a positive association between firm size and professional judgment. However, the results revealed no significant relationship between both variables, leading $H 5$ to be rejected.

The purpose of this study was to examine the factors influencing professional judgment of Malaysian auditors. Influencing factors were classified as personal factors and organizational factors. The multiple regression results showed that the position level and experience to be statistically significant in determining the level of professional judgment of auditors. Gender, knowledge and firm size have no significant relationship with professional judgment. As for gender, past research has shown mixed results and this study proves that there is no gender differences 
among Malaysian auditors in terms of their professional judgment. Even though past research has shown that knowledge has a positive relationship with professional judgment, this study finds no significant relationship between the two variables. With regard to firm size, this study finds similar results of prior Malaysian study (Haron et al., 2014) that there is no significant relationship between firm size and judgment.

This study offers several implications. In terms of the practical implications, this study provides insights into significant factors that influence professional judgment of Malaysian auditors. Besides, the management of audit firms can place emphasis on establishing training to their employees especially for the junior staff. Exposing junior auditors at the early stage might improve their professional judgment when facing with complexities of assignments. Despite the implications, this study is still subject to several limitations. The limitations may affect the usefulness and generalizability of this study. However, they can serve as basis for future research. First, this study used representative sampling and it may not be representative of Malaysian auditors because of the small sample size. Future studies should attempt for a larger sample size than this study for representativeness of the Malaysian auditor's population. Secondly, this study involves the use of questionnaire survey only. Future studies may attempt to adopt a different approach such as the interviews or case study questions to better evaluate the factors influencing professional judgment of auditors.

\section{Acknowledgement}

This work was funded by Universiti Pendidikan Sultan Idris under University Research Grant Code 2017-0516-106-01.

\section{References}

Aasmund, E., William, F., Messier, Jr., Steven, M. G. , Douglas, F. P., Samsuwated, Z. M. A., ... Aida, H. I. R. J. J. (2014). Principle of Auditing \& Assurance Services in Malaysia. McGraw Hill Book Education.

Abu Bakar, N. B., \& Ahmad, M. (2009). Auditor Independence: Malaysian Accountants ' Perceptions. International Journal of Business and Management, 4(12), 129-141. Retrieved from www.ccsenet.org/journal.html

Agoglia, C. P., Doupnik, T. S., \& Tsakumis, G. T. (2011). Principles-based versus rules-based accounting standards: The influence of standard precision and audit committee strength on financial reporting decisions. Accounting Review, 86(3), 747-767. https://doi.org/10.2308/accr.00000045

Bennett, B., Bradbury, M., \& Prangnell, H. (2006). Rules, principles and judgments in accounting standards. Abacus, 42(2), 189-204. https://doi.org/10.1111/j.1467-6281.2006.00197.x

Bhattacharjee, S., \& Moreno, K. (2002). The Impact of Affective Information on the Professional Judgments of More Experienced and Less Experienced Auditors. Journal of Behavioral Decision Making, 15(4), 361-377. https://doi.org/10.1002/bdm.420

Emby, C., \& Gibbins, M. (1987). Good judgment in public accounting: Quality and justification. Contemporary Accounting Research, 4(1), 287-313. https://doi.org/10.1111/j.1911-3846.1987.tb00668.x

Farma, I., Karamoy, H., \& Datu, C. (2016). Analisis Faktor- Faktor Audit Judgment. Jurnal EMBA, 5(1), 20-29.

Fumagalli, M., Ferrucci, R., Mameli, F., Marceglia, S., Mrakic-Sposta, S., Zago, S., ... Priori, A. (2010). Gender-related differences in moral judgments. Cognitive Processing, 11(3), 219-226. https://doi.org/10.1007/s10339-009-0335-2

Haron, H., Ismail, I., Ibrahim, D. N., \& Na, A. Lo. (2014). Factors influencing ethical judgment of auditors in Malaysia. Malaysian Accounting Review, 13(2).

Heyrani, F., Banimahd, B., \& Roudposhti, F. R. (2016). Investigation of the Effect of Auditors' Professionalism Levels on their Judgment to Resolve the Conflict between Auditor and Management. Procedia Economics and Finance, 36(16), 177-188. https://doi.org/10.1016/S2212-5671(16)30029-6

Jamilah, S., Fanani, Z., \& Chandr, G. (2007). Pengaruh Gender, Tekanan Ketaatan, dan Kompleksitas Tugas terhadap Audit Judgment. Simposium Nasional Akuntansi 10, 1-30.

Limen, M. M. P., Karamoy, H., \& Gamaliel, H. (2017). Analisi faktor-faktor yang mempengaruhi audit judgment pada auditor. Jurnal Riset Akuntansi Going Concern, 12(2).

Mala, R., \& Chand, P. (2014). Impacts of additional guidance provided on international financial reporting standards on the judgments of accountants. International Journal of Accounting, 49(2), 263-288. https://doi.org/10.1016/j.intacc.2014.04.008 
Mala, R., \& Chand, P. (2015). Judgment and decision-making research in auditing and accounting: Future research implications of person, task, and environment perspective. Accounting Perspectives, 14(1), 1-50. https://doi.org/10.1111/1911-3838.12040

Mansouri, A., Pirayesh, R., \& Salehi, M. (2009). Audit Competence and Audit Quality: Case in Emerging Economy. International Journal of Business and Management, 4(2), 17-25. https://doi.org/10.5539/ijbm.v4n2p17

Pajouh, M. S., \& Martin, M. (2018). The Impact of Culture on Globalisation and Role of Women in Management : The case of the Iranian Hotel Industry.

Patel, C., Harrison, G. L., \& McKinnon, J. L. (2002). Cultural influences on judgments of professional accountants in auditor-client conflict resolution. Journal of International Financial Management \& Accounting, 13(1), 1-31.

Ponemon, L. A. (1990). Ethical judgments in accounting: A cognitive developmental perspective. Critical Perspectives on Accounting, 1(December 1989), 191-215.

Psaros, J., \& Trotman, K. T. (2004). The impact of the type of accounting standards on preparers' judgments. Abacus, 4O(1), 76-93. https://doi.org/10.1111/j.1467-6281.2004.00144.x

Ríos-figueroa, C. B., \& Este, U. (2013). Does experience affect auditors' professional judgment? evidence from puerto rico, 5(2), 13-32.

Setiawan, W. Y. (2018). Gender Differences in Auditors' Judgments: Evidence from Indonesia. Review of Integrative Business and Economics Research, 7(1), 350-358.

Smieliauskas, W. (2012). Principles-Based Reasoning about Accounting Estimates. Accounting Perspectives, 11(4), 259-296. https://doi.org/10.1111/1911-3838.12001

Wedemeyer, P. D. (2010). A discussion of auditor judgment as the critical component in audit quality- A practitioner's perspective. International Journal of Disclosure and Governance, 7(4), 320-333. https://doi.org/10.1057/jdg.2010.19

\section{Copyrights}

Copyright for this article is retained by the author(s), with first publication rights granted to the journal.

This is an open-access article distributed under the terms and conditions of the Creative Commons Attribution license (http://creativecommons.org/licenses/by/4.0/). 